IZA DP No. 5154

Women Move Differently: Job Separations and Gender

Boris Hirsch

Claus Schnabel

August 2010 


\title{
Women Move Differently: Job Separations and Gender
}

\author{
Boris Hirsch \\ University of Erlangen-Nuremberg \\ Claus Schnabel \\ University of Erlangen-Nuremberg \\ and IZA

\section{Discussion Paper No. 5154 \\ August 2010}

\author{
IZA \\ P.O. Box 7240 \\ 53072 Bonn \\ Germany \\ Phone: +49-228-3894-0 \\ Fax: +49-228-3894-180 \\ E-mail: iza@iza.org
}

\begin{abstract}
Any opinions expressed here are those of the author(s) and not those of IZA. Research published in this series may include views on policy, but the institute itself takes no institutional policy positions.

The Institute for the Study of Labor (IZA) in Bonn is a local and virtual international research center and a place of communication between science, politics and business. IZA is an independent nonprofit organization supported by Deutsche Post Foundation. The center is associated with the University of Bonn and offers a stimulating research environment through its international network, workshops and conferences, data service, project support, research visits and doctoral program. IZA engages in (i) original and internationally competitive research in all fields of labor economics, (ii) development of policy concepts, and (iii) dissemination of research results and concepts to the interested public.
\end{abstract}

IZA Discussion Papers often represent preliminary work and are circulated to encourage discussion. Citation of such a paper should account for its provisional character. A revised version may be available directly from the author. 
IZA Discussion Paper No. 5154

August 2010

\section{ABSTRACT}

\section{Women Move Differently: Job Separations and Gender}

Using a large German linked employer-employee data set and methods of competing risks analysis, this paper investigates gender differences in job separation rates to employment and nonemployment. In line with descriptive evidence, we find lower job-to-job and higher job-to-nonemployment transition probabilities for women than men when controlling for individual and workplace characteristics and unobserved plant heterogeneity. These differences vanish once we allow these characteristics to affect separations differently by gender. When additionally controlling for wages, we find that both separation rates are considerably lower and also significantly less wage-elastic for women than for men.

JEL Classification: J62, J63, J16

Keywords: job separations, gender, gender pay gap, Germany

Corresponding author:

Claus Schnabel

Friedrich-Alexander-Universität Erlangen-Nürnberg

Lehrstuhl für Arbeitsmarkt- und Regionalpolitik

Lange Gasse 20

90403 Nürnberg

Germany

E-mail: claus.schnabel@wiso.uni-erlangen.de 


\section{Introduction}

In most countries, women have traditionally shown a lower attachment to the labour force in that they have higher propensities to quit jobs and to leave employment than men. While job separation rates differ substantially between countries, a recent comparative analysis by the OECD (2010) makes clear that women have higher separation rates than men in almost all OECD countries. This even holds when controlling for industry, age, and educational attainment. It would be interesting to know, however, whether this is still true when taking into account further individual and workplace characteristics and when distinguishing separations to employment from those to nonemployment.

The likelihood and the determinants of a job separation of a woman compared to a man are particularly relevant from an employer's perspective. For instance, firms may place (particular groups of) employees with higher job separation probabilities in jobs with lower training and/or reduced career opportunities, thus avoiding to lose human capital investments. Statistical discrimination of this kind is likely to be one of the main sources of the gender pay gap. While this consequence of gender differences in job separation rates is also relevant from the point of view of a policy-maker, she may be equally interested to find out whether and why women are more likely to end up in nonemployment since this could impede future labour market prospects.

That distinguishing job-to-job from job-to-nonemployment transitions (rather than looking at the overall separation rate) is quite important has been shown by Royalty (1998) in an empirical analysis for the U.S.1 In particular, she finds that the gender difference in overall separations rates is rather low due to offsetting influences of higher job-to-job turnover for men and higher job-to-nonemployment turnover for women. Moreover, a recent study by Frederiksen (2008) for private sector employees in Denmark points at the importance of including both information on individuals and workplaces to take account of labour market segregation ${ }^{2}$ Confirming Royalty's results, Frederiksen finds that women are more likely to separate to nonemployment and less likely to make job-to-job transitions, but there is no gender difference in the overall separation rate.

Building on these insights, this paper utilises linked employer-employee data for western Germany to investigate gender differences in the separations rates to employment and nonemployment. Our data allow us to improve in several ways upon Frederiksen (2008), whose snapshot data - though comprehensive in coverage - only refer to a specific day in November of each year and contain few workplace characteristics (just establishment size and payroll per employee). First, our data set comprises

$1 \quad$ Earlier studies investigating gender differences in overall job separation rates but not distinguishing job separations by destination state include Viscusi (1980), Blau and Kahn (1981), as well as Light and Ureta (1992).

2 For an empirical study investigating worker turnover utilising only workplace characteristics, see Anderson and Meyer (1994). 
much more workplace characteristics, including workforce composition, the industrial relations regime, and profitability, as well as additional information on individuals, such as nationality and tenure. This enables us to account more adequately for observed heterogeneity, in particular at the level of the establishment, and to identify hitherto neglected forces that might drive gender differences in job separations. Second, since we have information on the employment spell length on a daily basis, we can make use of continuous hazard rate modelling techniques and are thus able to control for unobserved heterogeneity at the establishment level by fitting stratified Cox models. Third, this allows us to account comprehensively for potential gender segregation effects in the labour market reflected in both observed and unobserved plant characteristics. That said, the main limitation of our data set is that it does not contain (reliable) information on workers' marital status and number of children.

The paper is organised as follows: Section 2 sets up our empirical specification, while Section 3 describes our linked employer-employee data. Our results are presented and discussed in Section 4, and Section 5 concludes.

\section{Empirical Specification}

To investigate gender differences in job separations, we will employ methods of competing risks survival analysis, i.e. we will fit competing risks models.$^{3}$ Standard univariate survival analysis models the time spent in a given state before transition to another state. This gives rise to a single hazard rate function, which is the instantaneous probability of leaving the state at some time $t$ conditional on survival up to $t$. Other than univariate survival analysis, competing risks survival analysis allows for the possibility that subjects may exit into more than just one destination state. The term 'competing risks' is used because the subject is confronted with exit probabilities into different, mutually exclusive destination states. By modelling these different destination-specific hazard functions, competing risks models serve as models of multivariate survival analysis.

More concretely, suppose there are $M$ workers (indexed $m=1, \ldots, M$ ) with $N$ employment spells (indexed $i=1, \ldots, N$ ) who work for $J$ firms (indexed $j=1, \ldots, J$ ). An employment spell is the period from the beginning until the end of a worker's employment relationship within a particular firm. A worker can exit employment via two possible routes: The worker can either change his or her employer, i.e. he or she separates to employment (route $e$ ), or can change to nonemployment (route $n$ ). Let $T^{r}$ denote the latent spell duration for exit via route $r$ with $r=e, n$. $T^{r}$ thus gives the spell duration if there were no other routes than $r$, which may cause the employment spell to end. $T^{r}$ is latent because the duration of an employment spell is either censored, i.e. no exit takes

3 For details about competing risks models we refer to Cameron and Trivedi (2005, pp. 640-664) and Jenkins (2005, pp. 91-112). 
place during observation, or ends with a separation to employment or nonemployment. Hence, the observed duration for the $i$-th employment spell $T_{i}$ is given by

$$
T_{i}=\min \left\{T_{i}^{e}, T_{i}^{n}, T_{i}^{c}\right\}
$$

where $T_{i}^{c}$ refers to the duration of a censored employment spell without any exit during the period of observation.

Let $s_{i}^{e}(t)$ denote the latent instantaneous separation rate to employment at time $t$ and $s_{i}^{n}(t)$ the latent instantaneous separation rate to nonemployment at time $t$, where $t$ corresponds to the time elapsed since the beginning of the spell, that is the worker's tenure. Let further $s_{i}(t)$ denote the overall instantaneous separation rate at time $t$. Assuming (conditional) independence in competing risks, i.e. latent failure times and thus routespecific hazard rates are (conditionally) independent, we arrive at

$$
s_{i}(t)=s_{i}^{e}(t)+s_{i}^{n}(t)
$$

The overall separation rate is then the sum of the two route-specific separation rates. Under the independence in competing risks assumption, the estimation of the competing risks model becomes straightforward: We just have to estimate two separate hazard rate models for the instantaneous separation rates to employment and nonemployment, where exits via the other route are considered as censored spells.

In a next step, we have to model the route-specific separation rates $s_{i}^{e}$ and $s_{i}^{n}$. Let $x_{i}^{r}(t)=\left(x_{i 1}^{r}(t), \ldots, x_{i k}^{r}(t)\right)$ denote a vector of $k$ time-varying covariates observed for employment spell $i$ at time $t$ with $r=e, n$. Next, let $\beta^{r}=\left(\beta_{1}^{r}, \ldots, \beta_{k}^{r}\right)^{\top}$ denote a vector of $k$ coefficients which are the same for all spells $i$ and constant over time. Analogously, $z_{j(i)}^{r}(t)=\left(z_{j(i) 1}^{r}(t), \ldots, z_{j(i) l}^{r}(t)\right)$ is a vector of $l$ time-varying covariates observed for firm $j(i)$ at time $t$, for which the worker with spell $i$ is working, while $\gamma^{r}=\left(\gamma_{1}^{r}, \ldots, \gamma_{l}^{r}\right)^{\top}$ denotes the corresponding vector of $l$ coefficients. We model the instantaneous separation rate via route $r$ of the $i$-th spell at time $t$ conditional on $x_{i}^{r}(t)$ and $z_{j(i)}^{r}(t)$ as

$$
s_{i}^{r}\left[t \mid x_{i}^{r}(t), z_{j(i)}^{r}(t)\right]=s_{0 j(i)}^{r}(t) \exp \left[x_{i}^{r}(t) \beta^{r}+z_{j(i)}^{r}(t) \gamma^{r}\right] .
$$

Equation (3) therefore defines conditional proportional hazard functions with firm-specific baseline hazard $s_{0 j(i)}^{r}(t)$ that reflects unobserved heterogeneity at the level of the firm. Put differently, the impact of the worker's tenure on his or her instantaneous separation rate to employment or nonemployment is allowed to be firm-specific. Leaving $s_{0 j(i)}^{r}(t)$ an unspecified nonnegative function of the worker's tenure $t$, we arrive at two stratified Cox models with time-varying covariates, where Cox's $(1972 ; 1975)$ partial likelihood estimator allows us to estimate $\beta^{r}$ and $\gamma^{r}$ conditionally on firm-specific unobserved heterogeneity 
without the need of identifying it $4^{4}$ In principle, this stratified partial likelihood estimator bears a lot of similarity to the within estimator for the linear fixed effects model (cf., e.g., Ridder and Tunall, 1999). As stated above, the estimation of the competing risks model is then achieved by separate estimation of these two models.

If $x_{i}^{r}(t)$ includes a (time-invariant) female dummy $f_{e} m_{i}$, which is one if spell $i$ is an employment spell of a woman and zero otherwise, then

$$
\frac{\partial \ln s_{i}^{r}\left[t \mid x_{i}^{r}(t), z_{j(i)}^{r}(t)\right]}{\partial \mathrm{fem}_{i}}=\beta_{f e m}^{r},
$$

where $\beta_{\text {fem }}^{r}$ denotes the route-specific coefficient of the female dummy. Hence, $\exp \beta_{\text {fem }}^{r}-1$ gives the percentage gender difference in the instantaneous route-specific separation rate.

\section{Data}

The data set used in subsequent empirical analyses is the German LIAB, i.e. the Linked Employer-Employee Data Set of the Institute for Employment Research (Institut für Arbeitsmarkt- und Berufsforschung, IAB) of the German Federal Employment Agency (Bundesagentur für Arbeit). The LIAB is created by linking the process-produced personspecific data of the IAB with the IAB Establishment Panel (cf. Alda et al., 2005). Using the LIAB we are therefore able to control both for individual and workplace characteristics.

The employee history used for constructing the LIAB is based on the integrated notification procedure for the health, pension, and unemployment insurances 5 This procedure requires all employers to report all relevant information on their employees if covered by the social security system, where misreporting is legally prohibited. Notifications are compulsory both at the beginning and end of employment. Additionally, an annual report must be made for each employee employed on 31st of December of the year. As a consequence, only those workers, salaried employees, and trainees who are covered by social security are included. Thus, among others, civil servants, self-employed, those in marginal employment, students enrolled in higher education, and family workers are not included. All in all, about 80 per cent of all people employed in western Germany are part of the employee history.

The data include, among others things, information for every employee on the daily gross wage, censored at the social security contribution ceiling, on the employee's occupation and occupational status, on industry, and on the start and end of each employee notification. Furthermore, individual characteristics, such as age, sex, schooling, and nationality are contained. Due to notifications made in the case of changes which are

\footnotetext{
$4 \quad$ For details about (stratified) Cox models and their estimation via partial likelihood, see Therneau and Grambsch (2000) and Klein and Moeschberger (2003, pp. 243-328).

5 Details are given by Bender et al. (2000) and Alda et al. (2005).
} 
relevant according to benefit entitlement rules, the data set also comprises information on the employee's marital status and the number of children, but only in case of an unemployment spell, and these variables contain much measurement error. Therefore, we will not be able to use them as regressors. Finally, an establishment number is included which is used to link the employee history and the IAB Establishment Panel.

The employer side of our data set is given by the IAB Establishment Panel, a random sample of establishments (not firms) from the comprehensive Employment Statistics drawn according to the principle of optimal stratification. ${ }^{6}$ Strata are defined over plant sizes and industries, where all in all ten plant sizes and 16 industries are considered and large plants are oversampled. Since the survey is based on the Employment Statistics aggregated via the establishment number as of 30th of June of a year, it only includes establishments which employ at least one employee covered by social security. Every year since 1993 the IAB Establishment Panel has surveyed the same establishments from all industries in western Germany. Response rates of units which have been interviewed repeatedly exceed 80 per cent. The IAB Establishment Panel is created to serve the needs of the Federal Employment Agency, so that the focus on employment-related topics is predominant. Questions deal, among other things, with the number of employees, the working week for full-time workers, coverage by collective agreements, the existence of a works council, the establishment's performance, and the technological status of the plant.

Linking both the IAB Establishment Panel and the employee history through the establishment number gives the LIAB 7 We will use version 2 of the LIAB longitudinal model, which is based on a balanced panel of establishments participating in the IAB Establishment Panel in each year between 2000 and 2002 and provides information on all workers who have been employed by any of these establishments for at least one day. For all workers we have accurate information on their employment spells. Workers who are still employed by the same establishment at the 31st of December 2002 are treated as censored. For those who leave their establishments between 1st of January 2000 and 31st of December 2002, we know whether they move to another plant or whether they move to nonemployment 8 Therefore, we are able to construct the separation rates to employment and to nonemployment as discussed in Section 2, where employment refers to employment at another establishment. Separations into nonemployment end either in unemployment or are not recorded in the data anymore ('unknown'). The latter either implies that the person has changed to nonemployment without receiving benefits from the unemployment office or that the person has become, for instance, a self-employed not included in the employee history. While our data set does not enable us to disaggregate this category

Details about the IAB Establishment Panel are given by Kölling (2000).

For details about the different LIAB models and their versions, see Jacobebbinghaus (2008).

Note that our data set does not allow us to distinguish between voluntary quits and involuntary dismissals. A crude approximation, which is in line with empirical evidence from other German data sets (see, e.g., Burda and Mertens, 2001), would be that job-to-job moves are predominantly voluntary quits, while most of the separations to nonemployment may be involuntary dismissals. 
of unknown destination, information from other data sets suggests that the majority of employees in this category have indeed moved to nonemployment. 9 Therefore, we have pooled the separations to unemployment and the separations to 'unknown' to separations to nonemployment. We have not modelled them separately because the assumption of independent hazards of separating to unemployment and of separating to the 'unknown' group would clearly be erroneous.

We restrict our analysis to western Germany (since the eastern Germany labour market was still in a special transformation process in our observation period), to fulltime employees, and to establishments that employ at least five and no more than 1,000 employees ${ }^{10}$ This leaves us - after dropping establishments and their employees with missing values of the covariates in any of the years - with information on 216,032 employees, 57,898 of which are women and 158,134 are men, working in 3,010 establishments. Table 1 reports that 62,109 separations take place during our period of observation. 38,608 employees leave their establishments to join another company, while 23,501 workers exit to nonemployment. The remaining 153,923 workers are employed by the same establishment until 31st of December 2002. It turns out that the overall separation rate does not differ much by gender. There are marked gender differences, however, both in the separation rate to employment and to nonemployment. The separation rate to employment is about 2.4 percentage points larger for men, while the separation rate to nonemployment is about 1.9 percentage points larger for women. Hence, the descriptive analysis confirms the offsetting effect of separations to employment and non-employment found in earlier empirical studies.

Of course, this may change once we take other individual and workplace characteristics into account. Due to the inclusion of establishment data, we are able to control as well for person-specific characteristics as for characteristics of the establishment the employee is working for. In particular, by fitting stratified Cox models we can control for unobserved heterogeneity at the establishment level and thus for labour market sorting in a comprehensive way. The sample means of the covariates are displayed in the Appendix Table.

$9 \quad$ See, for example, Bartelheimer and Wieck (2005) for a transition matrix between employment and nonemployment based on the German Socio-Economic Panel, which allows stratification of the 'unknown' into detailed categories.

10 Since there is no detailed information on the number of hours worked, we exclude employees working part-time (at any time in the observation period). We further exclude establishments with a workforce of less than five and more than 1,000 employees because works councils, which cannot be set up in establishments with a workforce of less than five employees and which exist in virtually all establishments with more than 1,000 employees, are found to be one important determinant of both separations to employment and to nonemployment (e.g., Hirsch et al., 2010b). Moreover, apprentices and a small number of employees experiencing recalls are excluded. In addition, we keep only individuals which were on 1st of January 2000 between 16 and 55 years old, where the upper bound should ensure that the transitions into nonemployment are not due to (early) retirement. Finally, notifications which start and end at the same day and benefit notifications which correspond to employment notifications at the same time are deleted. 
Table 1: Worker separations (percentages in brackets)

\begin{tabular}{|c|c|c|c|c|c|c|c|c|}
\hline & \multicolumn{2}{|c|}{$\begin{array}{l}\text { Workers in } \\
\text { IAB Panel- } \\
\text { establishments }\end{array}$} & \multicolumn{6}{|c|}{$\begin{array}{c}\text { Separations } \\
01 / 01 / 2000-31 / 12 / 2002\end{array}$} \\
\hline & & & \multicolumn{2}{|c|}{ overall } & \multicolumn{2}{|c|}{ employment } & \multicolumn{2}{|c|}{ nonemployment } \\
\hline All & 216,032 & (100) & 62,109 & $(28.8)$ & 38,608 & $(17.9)$ & 23,501 & $(10.9)$ \\
\hline Female & 57,898 & (100) & 16,430 & $(28.4)$ & 9,309 & $(16.1)$ & 7,121 & $(12.3)$ \\
\hline Male & 158,134 & (100) & 45,679 & $(28.9)$ & 29,299 & (18.5) & 16,380 & (10.4) \\
\hline
\end{tabular}

Note: The data set used is version 2 of the LIAB longitudinal model. Only establishments with 5-1,000 employees and spells ending or beginning in 2000-2002 are considered.

A shortcoming of the LIAB is that daily gross wages, which are one of our covariates in later specifications, are censored at the social security contribution ceiling, viz. $€ 143.95$ in $2000, € 146.02$ in 2001 , and $€ 147.95$ in 2002 . This affects about 13.1 per cent of the spells in our sample. Obviously, using wage data without any correction would give biased estimates. However, any imputation of the censored values cannot completely remedy this problem since it would introduce, by construction, some measurement error. And this would cause inconsistent estimates of the impact of the wage if included as a regressor. In a first step, we therefore estimate the separation rates without the wage as regressor, and when including the log wage in a second step, we carry out our analysis only for those workers whose wages were always below the ceiling during the period of observation. This reduces the number of spells by 16.1 per cent for men and by 5.0 per cent for women.

\section{Results}

To investigate gender differences in job separation rates, we now fit conditionally independent competing risk models, where the route-specific separation rates are modelled as (stratified) Cox models. We include several covariates to control for both observed individual and workplace characteristics. To assess whether female workers have higher or lower separation rates to employment and nonemployment than males, we first of all include a female dummy. If we think of labour markets as search markets with significant search frictions, we expect women to have a lower separation probability to employment. This should reflect their lower average propensity of achieving better-paying jobs via voluntary job-to-job moves owing to domestic responsibilities, particularly when children 
are present ${ }^{11}$ This is in line with the empirical finding of more severe search frictions for women (e.g., Manning, 2003, pp. 44-49; Hirsch, 2010, pp. 168-173) and is likely to be one of the driving forces behind the gender pay gap: If women engage less in job shopping, which one source of (early-career) wage growth, they should find it harder to work their way up the wage distribution than men and thus achieve lower wages on average. With respect to job-to-nonemployment transitions, we expect women to have a higher separation rate, again mainly due to domestic responsibilities lowering their labour market attachment, such as child care and elderly care, but also because of gender differences in preferences for non-market time.

Other individual characteristics controlled for are the worker's nationality (i.e., a nonGerman dummy), his or her age (nine dummies), formal education (six dummies), and occupation (ten dummies). If search frictions in the labour market are significant, older workers should find themselves in better jobs on average. This simply reflects their longer search activity, giving rise to better matches on average. Accordingly, workers' age should be negatively related to their separation rates to employment and nonemployment as both the worker and the employer should be more reluctant to dissolve these better matches either by voluntary quits or by involuntary dismissals. With respect to nonemployment, however, this may hold less for workers near retirement who may also have an incentive to leave jobs to nonemployment due to generous early-retirement options and welfare payments for old unemployed, suggesting an inversely u-shaped relationship between the workers' age and their transition probability into nonemployment.

Regarding education, higher degrees of formal education should reflect higher productivity both in terms of signalling productivity and of higher investments in human capital. Since we expect workers with higher formal qualification and thus higher productivity to face less severe search frictions, which is in line with empirical studies investigating group-specific differences in search frictions, such as van den Berg and Ridder (1998), Postel-Vinay and Robin (2002), and Manning (2003, pp. 44-49), their separation rate to employment should be higher. Moreover, employers should be less inclined to lay off these workers due to the higher match-specific rents involved, therefore reducing the separation rate to nonemployment for more qualified individuals. Similarly, we argue that workers in occupations requiring more skills should exhibit lower separation rates to both employment and nonemployment, so that controlling for the worker's occupation is important, too.

To control for observed heterogeneity in workplace characteristics, we include several establishment covariates: First of all, the separation rates to employment and nonemployment may differ by sector, so we include ten sectoral dummies in the non-

$11 \quad$ As already said in Section 3, we unfortunately do not have (reliable) information on workers' marital status and number of children, which would allow us to investigate this conjecture in more detail. We would expect the gender difference mainly to show up for married women with children and a much weaker difference, if any at all, for childless singles. 
stratified Cox models ${ }^{12}$ Next, the establishment's industrial relations regime should play a role in workers' job-to-job and job-to-nonemployment transition behaviour. The representation of workers' interests by a works council or a union via collective agreements may, on the one hand, improve morale and reduce the separation rate to employment via a collective-voice effect and, on the other hand, reduce the separation rate to nonemployment by insuring employees against dismissals (as is found for works council existence by Hirsch et al., 2010b). Hence, we add dummies for works council existence and the existence of a collective agreement at the firm or sector level. Furthermore, the establishment's workforce composition and its size may also be important for workers' transition behaviour, in particular if occupational segregation plays a role. We therefore include the proportions of female, qualified, and fixed-term workers in the establishment's workforce as well as establishment size and its square as additional covariates. Finally, the establishment's profitability and technological status may have an influence on transition behaviour, as well. Establishments with good economic performance and new production technology may be more attractive employers, thus lowering the worker's separation rate to employment. Establishments with poor economic performance, however, should be forced lay off workers more often, so that workers in these establishments should exhibit a higher separation rate to nonemployment.

Eventually, additional covariates capturing overall (labour) market conditions are added: The lagged regional unemployment rate is included to take local labour market conditions into account, while a set of year dummies is to capture potential cyclical influences. In the following, we shall discuss the results of our conditionally independent competing risk models separately by route, starting with job-to-job transitions.

\subsection{Separation Rate to Employment}

As a baseline, we fit a standard Cox model for the instantaneous separation rate to employment including all the covariates discussed above, the results of which are shown in the first column of Table 2. This uses 216,032 employment spells, where 38,608 of the spells end with a job-to-job move. We find that women are less likely to change jobs. Their separation rate to employment is 10.2 percentage points lower than men's, where this gender difference is statistically significant at the 1 per cent level ${ }^{13}$

Yet, this standard Cox specification does only control for observed workplace

12 The sectors distinguished are (1) agriculture, hunting, and forestry (including fishing), (2) mining, quarrying, electricity, gas, and water supply, (3) manufacturing, (4) trade and repair, (5) construction, (6) transport, storage, and communication, (7) financial intermediation, (8) business activities, (9) other activities, as well as (10) non-profit organisations and public administration.

13 Note that a plot of the Nelson-Aalen baseline hazard after the Cox regression points at an overall negative duration dependence (see Appendix Figure A.1). This seems plausible: The longer a worker stays in a specific match, the better should have been that match on average, and therefore the lower should be his or her separation probability to employment. 
Table 2: Determinants of workers' instantaneous separation rate to employment

\begin{tabular}{|c|c|c|c|c|c|c|c|c|}
\hline \multirow{3}{*}{$\begin{array}{l}\text { Regressors } \\
\text { Female (dummy) }\end{array}$} & \multirow{2}{*}{\multicolumn{2}{|c|}{ Cox model }} & \multirow{2}{*}{\multicolumn{2}{|c|}{$\begin{array}{l}\text { Stratified Cox } \\
\text { model }\end{array}$}} & \multicolumn{4}{|c|}{$\begin{array}{l}\text { Fully interacted stratified Cox } \\
\text { model }\end{array}$} \\
\hline & & & & & \multicolumn{2}{|c|}{ Baseline } & \multicolumn{2}{|c|}{$\times$ Female } \\
\hline & -.108 & $(.014)$ & -.036 & $(.014)$ & -.088 & $(.153)$ & \multicolumn{2}{|c|}{-} \\
\hline Non-German (dummy) & -.138 & $(.021)$ & -.137 & $(.020)$ & -.151 & $(.022)$ & .057 & $(.048)$ \\
\hline Age under 21 years (ref. group) & \multicolumn{2}{|c|}{ - } & \multicolumn{2}{|c|}{ - } & \multicolumn{2}{|r|}{-} & \multicolumn{2}{|c|}{-} \\
\hline Age $21-25$ years (dummy) & -.287 & $(.066)$ & -.141 & $(.067)$ & -.158 & $(.085)$ & .051 & $(.136)$ \\
\hline Age $26-30$ years (dummy) & -.464 & $(.065)$ & -.234 & $(.067)$ & -.261 & $(.084)$ & .100 & $(.135)$ \\
\hline Age $31-35$ years (dummy) & -.596 & $(.065)$ & -.356 & $(.066)$ & -.365 & $(.084)$ & .063 & $(.135)$ \\
\hline Age $36-40$ years (dummy) & -.712 & $(.065)$ & -.491 & $(.067)$ & -.475 & $(.084)$ & -.051 & $(.135)$ \\
\hline Age $41-45$ years (dummy) & -.797 & $(.066)$ & -.624 & $(.067)$ & -.597 & $(.084)$ & -.101 & $(.135)$ \\
\hline Age $46-50$ years (dummy) & -.902 & $(.066)$ & -.737 & $(.067)$ & -.705 & $(.084)$ & -.118 & $(.136)$ \\
\hline Age $51-55$ years (dummy) & -.925 & $(.067)$ & -.784 & $(.068)$ & -.783 & $(.085)$ & .031 & $(.138)$ \\
\hline Age $56-58$ years (dummy) & -.809 & $(.078)$ & -.691 & $(.075)$ & -.681 & $(.092)$ & -.030 & $(.164)$ \\
\hline No apprenticeship, no Abitur (ref. group) & \multicolumn{2}{|c|}{ - } & \multicolumn{2}{|c|}{ - } & \multicolumn{2}{|c|}{ - } & \multicolumn{2}{|c|}{ - } \\
\hline Apprenticeship, no Abitur (dummy) & -.045 & $(.017)$ & .057 & $(.016)$ & .033 & $(.018)$ & .083 & $(.040)$ \\
\hline No apprenticeship, with Abitur (dummy) & .288 & $(.051)$ & .373 & $(.051)$ & .329 & $(.063)$ & .132 & $(.107)$ \\
\hline Apprenticeship and Abitur (dummy) & .089 & $(.028)$ & .192 & $(.028)$ & .167 & $(.034)$ & .070 & $(.060)$ \\
\hline Technical college degree (dummy) & .098 & $(.029)$ & .252 & $(.028)$ & .220 & $(.030)$ & .114 & $(.071)$ \\
\hline University degree (dummy) & .228 & $(.027)$ & .348 & $(.028)$ & .308 & $(.030)$ & .156 & $(.064)$ \\
\hline Basic manual occupation (ref. group) & \multicolumn{2}{|c|}{ - } & \multicolumn{2}{|c|}{ - } & \multicolumn{2}{|c|}{ - } & \multicolumn{2}{|c|}{-} \\
\hline Qualified manual occupation (dummy) & .029 & $(.018)$ & .007 & $(.017)$ & .012 & $(.018)$ & -.015 & $(.066)$ \\
\hline Engineers and technicians (dummy) & .120 & $(.021)$ & .034 & $(.020)$ & .041 & $(.021)$ & -.060 & $(.058)$ \\
\hline Basic service occupation (dummy) & .067 & $(.024)$ & .021 & $(.024)$ & .004 & $(.026)$ & .084 & $(.065)$ \\
\hline Qualified service occupation (dummy) & .095 & $(.046)$ & -.015 & $(.051)$ & -.070 & $(.078)$ & .085 & $(.100)$ \\
\hline Semi-professional (dummy) & -.064 & $(.036)$ & .059 & $(.040)$ & .080 & $(.051)$ & -.040 & $(.072)$ \\
\hline Professional (dummy) & .186 & $(.042)$ & .325 & $(.045)$ & .332 & $(.052)$ & -.105 & $(.092)$ \\
\hline Basic business occupation (dummy) & .198 & $(.027)$ & .121 & $(.029)$ & .147 & $(.036)$ & -.074 & $(.058)$ \\
\hline Qualified business occupation (dummy) & .153 & $(.019)$ & .047 & $(.020)$ & .042 & $(.023)$ & -.034 & $(.046)$ \\
\hline Manager (dummy) & .171 & $(.033)$ & .188 & $(.035)$ & .186 & $(.038)$ & -.030 & $(.090)$ \\
\hline Works council (dummy) & -.130 & $(.018)$ & -.103 & $(.074)$ & -.125 & $(.075)$ & .136 & $(.047)$ \\
\hline Coll. agreement at sector level (dummy) & -.130 & $(.016)$ & -.353 & $(.047)$ & -.354 & $(.049)$ & -.000 & $(.038)$ \\
\hline Coll. agreement at firm level (dummy) & -.022 & $(.021)$ & -.219 & $(.058)$ & -.211 & $(.059)$ & -.046 & $(.053)$ \\
\hline Proportion of female workers & -.219 & $(.030)$ & 1.029 & $(.143)$ & 1.110 & $(.144)$ & -.204 & $(.061)$ \\
\hline Proportion of qualified workers & .128 & $(.023)$ & 1.644 & $(.071)$ & 1.636 & $(.072)$ & -.018 & $(.059)$ \\
\hline Proportion of fixed-term workers & .196 & $(.056)$ & -1.781 & $(.168)$ & -1.667 & $(.171)$ & -.326 & $(.136)$ \\
\hline Bad economic performance (dummy) & .531 & $(.011)$ & .483 & $(.022)$ & .499 & $(.022)$ & -.098 & $(.028)$ \\
\hline New production technology (dummy) & -.029 & $(.012)$ & -.163 & $(.023)$ & -.188 & $(.024)$ & .104 & $(.031)$ \\
\hline Establishment size / 1000 & -.528 & $(.079)$ & -.396 & $(.432)$ & -.340 & $(.434)$ & -.214 & $(.202)$ \\
\hline Establishment size / 1000 squared & 1.199 & $(.078)$ & -.219 & $(.386)$ & -.243 & $(.389)$ & .145 & $(.205)$ \\
\hline Regional unemployment rate (lagged, \%) & .012 & $(.002)$ & -.076 & $(.020)$ & -.076 & $(.020)$ & .011 & $(.004)$ \\
\hline Year 2000 (ref. group) & & & & & & & & \\
\hline Year 2001 (dummy) & .294 & $(.013)$ & .190 & $(.030)$ & .220 & $(.032)$ & -.110 & $(.031)$ \\
\hline Year 2002 (dummy) & .173 & $(.014)$ & .286 & $(.038)$ & .333 & $(.039)$ & -.165 & $(.033)$ \\
\hline Ten sectoral dummies & \multicolumn{2}{|c|}{$(p<.001)$} & - & & & & & \\
\hline Observations & 580 & 409 & 580 & 409 & & & & \\
\hline Spells & 216 & 032 & 216 & 032 & & & 32 & \\
\hline Transitions & & 608 & & 608 & & & 08 & \\
\hline Log likelihood & -387 & 163 & -126 & 791 & & & & \\
\hline Pseudo- $R^{2}$ & & 096 & & 170 & & & 76 & \\
\hline
\end{tabular}

Notes: The data set used is version 2 of the LIAB longitudinal model. The dependent variable of the (stratified) Cox models is a dummy variable taking the value one if the individual changes from an IAB Panel-establishment to another establishment and zero otherwise. Standard errors clustered at the individual level are given in parentheses. Only establishments with 5-1,000 employees and spells ending or beginning in 2000-2002 are considered. 
heterogeneity. We therefore expect more reliable results from a stratified Cox model allowing the baseline hazard to be establishment-specific and estimating the covariates' coefficients without identifying the baseline, thus controlling for unobserved heterogeneity in workplace characteristics. In particular, this allows us to account for gender segregation effects reflected in observed and unobserved establishment characteristics.

Estimating the stratified Cox model, the results of which are presented in the second column of Table 2, we find that female workers still have a significantly lower separation rate to employment than males. Although the difference between women's and men's separation rates of 3.5 percentage points is reduced to only about one third of the difference found in the standard Cox model, it is still significant at the 1 per cent level. This result is in line with our hypothesis that women are less inclined to make wageincreasing voluntary job-to-job moves.

Most of the control variables included have the expected impact. Let us start with individual characteristics. First, non-German workers have a 12.8 percentage points lower separation rate to employment than Germans, where the difference is statistically significant at the 1 per cent level. Similar to our discussion of the lower separation rate of women, this may indicate higher search frictions for non-Germans caused, for example, by language barriers not fully mirrored in formal education and/or discrimination, which would be in line with previous findings (e.g., Manning, 2003, pp. 44-49; Hirsch, 2010, pp. 168-173). Second, older workers tend to have lower job-to-job transition rates than young workers; and, third, there are significant differences according to formal education and occupation.

Also workplace characteristics have a significant effect on workers' job-to-job transition probability. First, the industrial relations regime plays an important role. The separation rate to employment is markedly lowered by a collective agreement or a works council, though the latter effect is not significant at conventional levels. Second, the establishment's workforce composition has a significant impact: While both the proportions of female and qualified workers have a large, significantly positive impact on the separation probability to employment, the separation rate is inversely related to the proportion of fixed-term workers in the workforce. Third, the establishment's profitability status has a large, significant effect on the instantaneous job separation probability to employment, which is 62.1 percentage points larger when economic performance is bad. Fourth, the separation rate is also lowered significantly by new production technology.

While all these workplace characteristics turn out to be important determinants of workers' probability of job-to-job moves, they are all absent in previous empirical studies investigating the impact of individual and workplace characteristics on workers' job-to-job and job-to-nonemployment transition behaviour, such as Frederiksen (2008). Apart from the bias stemming from omitting these variables, existing studies do also not account for unobserved factors at the establishment level likely to impact the separation 
probabilities. This is particularly important as gender segregation effects reflected in unobserved establishment characteristics may be important. We therefore argue that our results, which are by and large consistent with earlier studies, are not only more informative by pointing at additional factors influencing workers' job-to-job transition behaviour, but are also more reliable by tackling unobserved heterogeneity in workplace characteristics.

In the stratified Cox model discussed so far, all gender differences in covariate impacts show up in the coefficient of the female dummy. However, it would be interesting to know whether the separation rate to employment is still lower for females when allowing the covariates to impact men's and women's job-to-job transition behaviour differently. The third and fourth column of Table 2 therefore show the results for a fully interacted stratified Cox model. While this model fits the data significantly better according to an (unreported) likelihood ratio test, it also points at several interesting gender differences in the impact of workplace characteristics on workers' job-to-job transition behaviour.

The separation probability for women is now 8.4 percentage points lower than that for men, though the coefficient of the female dummy is estimated with considerably lower precision and thus insignificant. While individual characteristics by and large do not impact men and women differently, several workplace characteristics do. We find a significantly negative effect of a works council on the separation rate to employment for men, whereas it does not show up for females, which corroborates earlier findings by Hirsch et al. (2010b) pointing at a lower collective-voice effect for female workers. Moreover, women's job-to-job transition probability is significantly less affected than men's by bad economic performance of the establishment they are working for, while the negative effect of new production technology on workers' separation rate to employment is less pronounced for women. Also changes in workforce composition affect women and men differently: There is a large, significantly positive relationship between the proportion of female workers in the establishment's workforce and the separation probability of both females and males, but this effect is significantly lower for women workers ${ }^{14}$ Eventually, an increase in the proportion of fixed-term employees in the workforce lowers the separation rate of women while leaving the separation probability of male workers unaltered.

Given these findings, we conclude that there are clear gender differences in the impact of workplace characteristics. It is therefore of crucial importance to control in a comprehensive way for workplace characteristics as their different impact by gender may otherwise show up in the coefficient of the catch-all female dummy, tempting

14 It is tempting to interpret this result as reflecting gender segregation in the labour market - with less attractive working conditions and more voluntary quits in more female-dominated establishments and men being more likely to voluntarily move out of these establishments than women. However, note that this interpretation is far-fetched given that the identification of the establishment characteristics' coefficients via stratified partial likelihood rests on within-establishment variation in these characteristics (see, e.g., Ridder and Tunalı, 1999). 
the researcher to draw premature conclusions. Let us now turn to the other route an employment spell might end by investigating the separation rate to nonemployment.

\subsection{Separation Rate to Nonemployment}

Again, we start by fitting a simple Cox model including all aforementioned covariates, the results of which are found in the first column of Table 3. This utilises 216,032 employments spells, where 23,501 of these spells end with a transition to nonemployment. We find that women are more likely to move to nonemployment. Their separation rate to nonemployment is 20.3 percentage points larger than the transition rate of males, where this difference is significant at the 1 per cent level ${ }^{15}$

The gender difference only slightly changes when fitting a stratified Cox model controlling for unobserved heterogeneity in workplace characteristics, the results of which are shown in the second column of Table 3. Women still have a significantly higher job-tononemployment transition probability. Their separation rate to non-employment is now 22.5 percentage points larger than men's. This is in line with our expectation that women are more likely to move out of employment for family-related reasons.

Most of the control variables have the impact expected. Regarding individual characteristics, we first of all find that non-German workers are significantly more likely to move to nonemployment. Their separation rate is 21.7 percentage points larger than Germans', the difference being significant at the 1 per cent level. Second, with respect to age, we get the expected inversely u-shaped relationship with prime-age workers being least likely to move into nonemployment. Third, we find considerable differences according to formal education and occupation.

The controls for workplace characteristics also affect workers' job-to-nonemployment transition behaviour significantly. First, the industrial relations regime is of importance as is seen by the negative impact of a collective agreement at the sector level on the separation rate to nonemployment. Second, the establishment's workforce composition affects the separation rate to nonemployment: It increases with the proportion of qualified workers in the establishment's workforce. Third, the establishment's profitability status shows the expected impact. Bad economic performance yields a 8.4 percentage points larger job-to-nonemployment transition probability, where this effect is significant at the 1 per cent level.

Again, in this specification, all gender differences in the effects of the covariates are sponged up by the catch-all female dummy. We therefore fit a fully interacted stratified

15 A plot of the Nelson-Aalen baseline hazard after the Cox regression points at negative duration dependence in the first ten years of tenure and virtually no duration dependence afterwards (see Appendix Figure A.2. This seems plausible insofar as more tenured workers should be less likely to be dismissed than new entrants owing to their higher specific human capital and dismissal protection legislation, where this effect should add less and less to employees' employment stability when workers' tenure increases further. 
Table 3: Determinants of workers' instantaneous separation rate to non-employment

\begin{tabular}{|c|c|c|c|c|c|c|c|c|}
\hline \multirow{4}{*}{$\begin{array}{l}\text { Regressors } \\
\text { Female (dummy) } \\
\text { Non-German (dun }\end{array}$} & \multirow{2}{*}{\multicolumn{2}{|c|}{ Cox model }} & \multirow{2}{*}{\multicolumn{2}{|c|}{$\begin{array}{l}\text { Stratified Cox } \\
\text { model }\end{array}$}} & \multicolumn{4}{|c|}{$\begin{array}{l}\text { Fully interacted stratified Cox } \\
\text { model }\end{array}$} \\
\hline & & & & & \multicolumn{2}{|c|}{ Baseline } & \multicolumn{2}{|c|}{$\times$ Female } \\
\hline & .185 & $(.017)$ & .203 & $(.018)$ & -.066 & $(.126)$ & \multicolumn{2}{|c|}{-} \\
\hline & .219 & $(.021)$ & .197 & $(.022)$ & .204 & $(.025)$ & -.028 & $(.047)$ \\
\hline Age under 21 years (ref. group) & \multicolumn{2}{|c|}{ - } & \multicolumn{2}{|c|}{ - } & \multicolumn{2}{|c|}{ - } & \multicolumn{2}{|c|}{ - } \\
\hline Age $21-25$ years (dummy) & -.519 & $(.045)$ & -.444 & $(.046)$ & -.450 & $(.058)$ & -.015 & $(.093)$ \\
\hline Age $26-30$ years (dummy) & -.737 & $(.044)$ & -.620 & $(.046)$ & -.720 & $(.058)$ & .268 & $(.092)$ \\
\hline Age $31-35$ years (dummy) & -.869 & $(.044)$ & -.743 & $(.046)$ & -.855 & $(.057)$ & .346 & $(.091)$ \\
\hline Age $36-40$ years (dummy) & -1.001 & $(.044)$ & -.864 & $(.046)$ & -.892 & $(.058)$ & .076 & $(.093)$ \\
\hline Age $41-45$ years (dummy) & -1.068 & $(.045)$ & -.924 & $(.047)$ & -.900 & $(.059)$ & -.124 & $(.095)$ \\
\hline Age $46-50$ years (dummy) & -1.089 & $(.046)$ & -.951 & $(.048)$ & -.937 & $(.060)$ & -.059 & $(.097)$ \\
\hline Age $51-55$ years (dummy) & -.933 & $(.047)$ & -.766 & $(.049)$ & -.779 & $(.061)$ & .023 & $(.100)$ \\
\hline Age $56-58$ years (dummy) & -.431 & $(.063)$ & -.322 & $(.068)$ & -.379 & $(.083)$ & .163 & $(.146)$ \\
\hline No apprenticeship, no Abitur (ref. group) & \multicolumn{2}{|c|}{-} & \multicolumn{2}{|c|}{-} & \multicolumn{2}{|c|}{-} & \multicolumn{2}{|c|}{-} \\
\hline Apprenticeship, no Abitur (dummy) & -.329 & $(.019)$ & -.285 & $(.021)$ & -.310 & $(.024)$ & .082 & $(.044)$ \\
\hline No apprenticeship, with Abitur (dummy) & .643 & $(.049)$ & .610 & $(.052)$ & .669 & $(.067)$ & -.090 & $(.102)$ \\
\hline Apprenticeship and Abitur (dummy) & -.338 & $(.038)$ & -.314 & $(.040)$ & -.348 & $(.053)$ & .079 & $(.079)$ \\
\hline Technical college degree (dummy) & -.358 & $(.042)$ & -.345 & $(.045)$ & -.383 & $(.054)$ & .159 & $(.096)$ \\
\hline University degree (dummy) & -.222 & $(.038)$ & -.114 & $(.041)$ & -.113 & $(.049)$ & .025 & $(.081)$ \\
\hline Basic manual occupation (ref. group) & \multicolumn{2}{|c|}{ - } & \multicolumn{2}{|c|}{ - } & \multicolumn{2}{|c|}{ - } & \multicolumn{2}{|c|}{-} \\
\hline Qualified manual occupation (dummy) & -.177 & $(.022)$ & -.267 & $(.026)$ & -.281 & $(.028)$ & .152 & $(.071)$ \\
\hline Engineers and technicians (dummy) & -.567 & $(.033)$ & -.491 & $(.036)$ & -.493 & $(.040)$ & .049 & $(.086)$ \\
\hline Basic service occupation (dummy) & -.169 & $(.025)$ & -.147 & $(.031)$ & -.125 & $(.034)$ & -.026 & $(.065)$ \\
\hline Qualified service occupation (dummy) & -.337 & $(.054)$ & -.182 & $(.066)$ & -.143 & $(.107)$ & .026 & $(.125)$ \\
\hline Semi-professional (dummy) & -.458 & $(.039)$ & -.424 & $(.049)$ & -.547 & $(.078)$ & .258 & $(.093)$ \\
\hline Professional (dummy) & .059 & $(.051)$ & .112 & $(.060)$ & .108 & $(.072)$ & .014 & $(.108)$ \\
\hline Basic business occupation (dummy) & -.157 & $(.034)$ & -.202 & $(.041)$ & -.159 & $(.053)$ & -.051 & $(.075)$ \\
\hline Qualified business occupation (dummy) & -.354 & $(.025)$ & -.400 & $(.030)$ & -.470 & $(.037)$ & .103 & $(.056)$ \\
\hline Manager (dummy) & -.248 & $(.046)$ & -.116 & $(.050)$ & -.111 & $(.056)$ & -.092 & $(.115)$ \\
\hline Works council (dummy) & -.272 & $(.020)$ & -.021 & $(.088)$ & -.065 & $(.090)$ & .138 & $(.050)$ \\
\hline Coll. agreement at sector level (dummy) & -.126 & $(.019)$ & -.141 & $(.046)$ & -.143 & $(.048)$ & .007 & $(.046)$ \\
\hline Coll. agreement at firm level (dummy) & -.125 & $(.027)$ & -.081 & $(.059)$ & -.054 & $(.063)$ & -.070 & $(.065)$ \\
\hline Proportion of female workers & .021 & $(.036)$ & -.015 & $(.140)$ & .153 & $(.143)$ & -.399 & $(.080)$ \\
\hline Proportion of qualified workers & -.166 & $(.028)$ & .149 & $(.074)$ & .110 & $(.076)$ & .128 & $(.069)$ \\
\hline Proportion of fixed-term workers & 1.132 & $(.039)$ & -.042 & $(.133)$ & .011 & $(.136)$ & -.230 & $(.091)$ \\
\hline Bad economic performance (dummy) & .360 & $(.016)$ & .081 & $(.027)$ & .103 & $(.029)$ & -.064 & $(.038)$ \\
\hline New production technology (dummy) & -.076 & $(.015)$ & .035 & $(.026)$ & .028 & $(.028)$ & .032 & $(.036)$ \\
\hline Establishment size / 1000 & -1.404 & $(.103)$ & -1.038 & $(.542)$ & -1.290 & $(.548)$ & .688 & $(.253)$ \\
\hline Establishment size / 1000 squared & 1.087 & $(.110)$ & .616 & $(.508)$ & .815 & $(.514)$ & -.634 & $(.264)$ \\
\hline Regional unemployment rate (lagged, \%) & .008 & $(.002)$ & -.026 & $(.022)$ & -.026 & $(.022)$ & -.012 & $(.005)$ \\
\hline Year 2000 (ref. group) & & & & & & & & \\
\hline Year 2001 (dummy) & .109 & $(.016)$ & .113 & $(.034)$ & .069 & $(.036)$ & .123 & $(.037)$ \\
\hline Year 2002 (dummy) & .267 & $(.017)$ & .289 & $(.040)$ & .252 & $(.042)$ & .082 & $(.038)$ \\
\hline Ten sectoral dummies & \multicolumn{2}{|c|}{$(p<.001)$} & & & & & & \\
\hline Observations & & 409 & & 409 & & & & \\
\hline Spells & & 032 & & 032 & & & & \\
\hline Transitions & & 501 & & 501 & & & 501 & \\
\hline Log likelihood & -23 & 745 & & 148 & & & & \\
\hline Pseudo- $R^{2}$ & & 199 & & 168 & & & 87 & \\
\hline
\end{tabular}

Notes: The data set used is version 2 of the LIAB longitudinal model. The dependent variable of the (stratified) Cox models is a dummy variable taking the value one if the individual changes from an IAB Panel-establishment to non-employment and zero otherwise. Standard errors clustered at the individual level are given in parentheses. Only establishments with 5-1,000 employees and spells ending or beginning in 2000-2002 are considered. 
Cox model to investigate whether controls impact men and women differently, the results of which are presented in the third and fourth columns of Table 3 . First of all, the female dummy's coefficient is now negative, though insignificant. Women do not have a higher separation rate to nonemployment per se. Confirming our hypothesis that higher job-tononemployment turnover of women might be primarily due to family-related reasons, we find that only women aged 26 to 35 years have significantly larger separation rates to nonemployment than men of that age, whereas younger and older women do not differ in their separation rates from males. All in all, individual characteristics other than age do not seem to impact women and men differently.

Yet, some workplace characteristics do: While a works council has an insignificantly negative effect on the separation rate to nonemployment for men and an insignificantly positive one for women, the difference in these effects is significant, in line with earlier findings by Hirsch et al. (2010b) pointing at a less pronounced insurance effect of works councils for women compared to men. Also changes in the establishment's workforce composition reflected in the proportions of female and fixed-term employees in the workforce affect men and women differently. ${ }^{16}$

\subsection{Including the Wage as Regressor}

Lest to lose observations due to censored wage data, we have not included the worker's wage as a regressor in the competing risk models so far. Wages, however, might be important for at least two reasons. On the one hand, the wage is likely to be an important determinant of workers' turnover behaviour both into employment and nonemployment. The higher the wage paid, ceteris paribus, the lower should be the separation rate to employment as voluntary job-to-job moves are less likely to yield a wage gain for the worker. Moreover, a higher wage should also lower the transition probability into nonemployment, for individuals who are paid low wages are more likely to leave the labour market due to the availability of transfer payments or because they are more productive in household production. Put differently, the volume of voluntary transitions into nonemployment should depend negatively on the wage paid.

On the other hand, there are several studies pointing at more wage-elastic turnover of men compared to women (e.g., Barth and Dale-Olsen, 2009; Hirsch et al., 2010a; Ransom and Oaxaca, 2010). As these studies point out, gender differences in the wage elasticity of workers' turnover probabilities are likely to be an important source of the gender pay gap: If women are less likely to leave their employer for pecuniary considerations - for example, due to family-related reasons - employers may possess more wage-setting power

$\overline{16}$ Again, one might be tempted to tell a gender segregation story explaining the gender difference in the effect of the proportion of female workers in the establishment's workforce on workers' separation rate to nonemployment. But as explained in footnote 14, stratified partial likelihood estimation of the coefficients of the establishment characteristics relies on within-establishment variation, casting serious doubts on such an interpretation. 
over their female employees and exploit this to increase their profits at the detriment of women's wages. In short, this sort of monopsonistic or Robinsonian discrimination (due to Robinson (1933), who was the first to discuss it) requires women's labour supply at the level of the plant to be considerably less elastic than men's; and all the studies mentioned found gender differences in turnover behaviour large enough for this to hold empirically ${ }^{17}$ If women's transition behaviour is indeed driven less by their wages, it is also plausible to expect women to have lower separation rates to employment and nonemployment when controlling for the wage 18

We now redo our previous analysis by fitting fully interacted stratified Cox models for workers' instantaneous separation rates to employment and nonemployment adding workers' log wage as another covariate, the results of which are presented in Table 4. Since the wages contained in the LIAB are censored at the social security contribution ceiling, we only utilise employment spells with wages always below that ceiling $\sqrt{19}$ (For the details, see Section 3.) Hence, the following analysis uses only 187,702 employment spells, 32,548 of which end with a job-to-job move and 21,708 with a transition into nonemployment.

First of all, the competing risks model with wage as additional covariate fits the data significantly better as is seen by the marked increases in both route-specific log likelihoods. Since the coefficient of the log wage gives the wage elasticity of the respective separation rate, we affirm the findings of the studies mentioned earlier: Women's transition probabilities into employment and nonemployment are both significantly less wageelastic than men's. This holds even when controlling for unobserved heterogeneity in workplace characteristics, which previous studies were not able to do. Hence, our results are consistent with less elastic female labour supply at the plant level and point at the potential relevance of Robinsonian discrimination as one driving force of the gender pay gap 20 What is more, controlling for wage clearly affects the gender difference in transition probabilities: Women now show significantly smaller separation rates to both employment and nonemployment than men earning the same wage, reflecting their less wage-elastic

17 For more details about Robinsonian discrimination we refer to Hirsch $(2009 ; 2010)$.

18 Against this background, the negative (but due to the low precision in estimation insignificant) coefficient of the female dummy in the fully interacted stratified Cox model for the separation rate to nonemployment may be due to possible correlation of other control variables with the omitted wage of the worker.

19 As a check of robustness, we also estimated the following models by including a dummy for wage censoring rather than excluding spells with censored wages, where the dummy's coefficient captures the average wage effect for wage-censored observations. The results, which are available upon request, are affirmative to our findings from the models excluding censored spells presented below.

At this stage, one may object that part of the wage effect found may be demand-driven, rather than a supply-side response. However, since we control for both observed and unobserved determinants of establishment's layoff behaviour, we think this to be less of a problem. Note further that our sample does not include plant closings because it consists of a balanced panel of establishments. Nonetheless, we redid our analysis excluding downsizing establishments (i.e., establishments with an employment reduction of at least 25 per cent during our period of observation) as a check of robustness. We found that our results did not change qualitatively and are thus robust to this exercise. 
Table 4: Determinants of workers' instantaneous separation rates to employment and non-employment when the wage is included as regressor

\begin{tabular}{|c|c|c|c|c|c|c|c|c|}
\hline \multirow{4}{*}{$\begin{array}{l}\text { Regressors } \\
\text { Female (dummy) }\end{array}$} & \multicolumn{8}{|c|}{ Fully interacted stratified Cox models } \\
\hline & \multicolumn{4}{|c|}{$\begin{array}{l}\text { Separation rate to } \\
\text { employment }\end{array}$} & \multicolumn{4}{|c|}{$\begin{array}{c}\text { Separation rate to } \\
\text { non-employment }\end{array}$} \\
\hline & \multicolumn{2}{|c|}{ Baseline } & \multicolumn{2}{|c|}{$\times$ Female } & \multicolumn{2}{|c|}{ Baseline } & \multicolumn{2}{|c|}{$\times$ Female } \\
\hline & -.907 & $(.269)$ & & & -2.203 & $(.272)$ & & \\
\hline Log daily gross wage & -.860 & $(.041)$ & .166 & $(.060)$ & -2.137 & $(.046)$ & .480 & $(.063)$ \\
\hline Non-German (dummy) & -.177 & $(.024)$ & .087 & $(.049)$ & .145 & $(.026)$ & .043 & $(.048)$ \\
\hline Age under 21 years (ref. group) & \multicolumn{2}{|c|}{-} & \multicolumn{2}{|c|}{-} & \multicolumn{2}{|c|}{ - } & \multicolumn{2}{|c|}{-} \\
\hline Age $21-25$ years (dummy) & -.055 & $(.087)$ & .035 & $(.138)$ & -.198 & $(.073)$ & -.112 & $(.105)$ \\
\hline Age $26-30$ years (dummy) & -.086 & $(.085)$ & .074 & $(.137)$ & -.336 & $(.072)$ & .137 & $(.103)$ \\
\hline Age $31-35$ years (dummy) & -.135 & $(.085)$ & .001 & $(.137)$ & -.346 & $(.072)$ & .101 & $(.103)$ \\
\hline Age $36-40$ years (dummy) & -.252 & $(.085)$ & -.112 & $(.138)$ & -.342 & $(.072)$ & -.170 & $(.105)$ \\
\hline Age $41-45$ years (dummy) & -.374 & $(.086)$ & -.150 & $(.138)$ & -.378 & $(.073)$ & -.308 & $(.107)$ \\
\hline Age $46-50$ years (dummy) & -.473 & $(.086)$ & -.180 & $(.139)$ & -.432 & $(.074)$ & -.251 & $(.110)$ \\
\hline Age $51-55$ years (dummy) & -.511 & $(.087)$ & -.085 & $(.141)$ & -.289 & $(.076)$ & -.192 & $(.112)$ \\
\hline Age $56-58$ years (dummy) & -.345 & $(.097)$ & -.161 & $(.168)$ & .008 & $(.100)$ & .003 & $(.163)$ \\
\hline No apprenticeship, no Abitur (ref. group) & \multicolumn{2}{|c|}{ - } & \multicolumn{2}{|c|}{-} & \multicolumn{2}{|c|}{ - } & \\
\hline Apprenticeship, no Abitur (dummy) & .123 & $(.019)$ & .043 & $(.041)$ & -.076 & $(.025)$ & -.024 & $(.046)$ \\
\hline No apprenticeship, with Abitur (dummy) & .401 & $(.072)$ & .096 & $(.116)$ & .580 & $(.084)$ & -.020 & $(.119)$ \\
\hline Apprenticeship and Abitur (dummy) & .338 & $(.039)$ & -.021 & $(.064)$ & .032 & $(.059)$ & -.028 & $(.085)$ \\
\hline Technical college degree (dummy) & .443 & $(.042)$ & .094 & $(.081)$ & .115 & $(.065)$ & .120 & $(.106)$ \\
\hline University degree (dummy) & .652 & $(.044)$ & .065 & $(.076)$ & .583 & $(.061)$ & -.150 & $(.093)$ \\
\hline Basic manual occupation (ref. group) & \multicolumn{2}{|c|}{ - } & \multicolumn{2}{|c|}{ - } & \multicolumn{2}{|c|}{ - } & \multicolumn{2}{|c|}{-} \\
\hline Qualified manual occupation (dummy) & .066 & $(.019)$ & -.067 & $(.067)$ & -.161 & $(.030)$ & .070 & $(.074)$ \\
\hline Engineers and technicians (dummy) & .293 & $(.027)$ & -.163 & $(.064)$ & .079 & $(.047)$ & -.175 & $(.094)$ \\
\hline Basic service occupation (dummy) & -.013 & $(.027)$ & .083 & $(.065)$ & -.095 & $(.034)$ & -.018 & $(.067)$ \\
\hline Qualified service occupation (dummy) & .025 & $(.084)$ & .110 & $(.104)$ & .029 & $(.114)$ & .046 & $(.131)$ \\
\hline Semi-professional (dummy) & .268 & $(.058)$ & -.052 & $(.077)$ & -.091 & $(.083)$ & .139 & $(.096)$ \\
\hline Professional (dummy) & .630 & $(.074)$ & -.116 & $(.116)$ & .616 & $(.092)$ & -.006 & $(.127)$ \\
\hline Basic business occupation (dummy) & .270 & $(.043)$ & -.110 & $(.063)$ & .199 & $(.060)$ & -.226 & $(.080)$ \\
\hline Qualified business occupation (dummy) & .199 & $(.028)$ & -.078 & $(.050)$ & -.077 & $(.041)$ & -.014 & $(.061)$ \\
\hline Manager (dummy) & .612 & $(.066)$ & -.142 & $(.123)$ & .636 & $(.088)$ & -.238 & $(.148)$ \\
\hline Works council (dummy) & -.039 & $(.083)$ & .135 & $(.051)$ & -.025 & $(.098)$ & .136 & $(.054)$ \\
\hline Coll. agreement at sector level (dummy) & -.277 & $(.052)$ & -.026 & $(.041)$ & -.085 & $(.051)$ & -.107 & $(.050)$ \\
\hline Coll. agreement at firm level (dummy) & -.193 & $(.063)$ & -.031 & $(.056)$ & -.045 & $(.070)$ & -.084 & $(.069)$ \\
\hline Proportion of female workers & 1.086 & $(.154)$ & -.155 & $(.069)$ & .056 & $(.152)$ & -.156 & $(.089)$ \\
\hline Proportion of qualified workers & 1.579 & $(.075)$ & -.015 & $(.063)$ & .144 & $(.082)$ & .092 & $(.075)$ \\
\hline Proportion of fixed-term workers & -1.512 & $(.175)$ & -.269 & $(.142)$ & -.156 & $(.141)$ & .090 & $(.098)$ \\
\hline Bad economic performance (dummy) & .501 & $(.025)$ & -.123 & $(.031)$ & .099 & $(.030)$ & -.104 & $(.041)$ \\
\hline New production technology (dummy) & -.209 & $(.026)$ & .090 & $(.033)$ & .003 & $(.030)$ & .042 & $(.038)$ \\
\hline Establishment size / 1000 & -.246 & $(.467)$ & -.225 & $(.219)$ & -1.283 & $(.574)$ & .541 & $(.275)$ \\
\hline Establishment size / 1000 squared & -.824 & $(.420)$ & .213 & $(.224)$ & .791 & $(.538)$ & -.469 & $(.288)$ \\
\hline Regional unemployment rate (lagged, \%) & -.050 & $(.021)$ & .015 & $(.004)$ & -.002 & $(.023)$ & -.002 & $(.005)$ \\
\hline Year 2000 (ref. group) & & & & & & & & \\
\hline Year 2001 (dummy) & .176 & $(.034)$ & -.054 & $(.033)$ & .111 & $(.038)$ & .136 & $(.039)$ \\
\hline Year 2002 (dummy) & .283 & $(.042)$ & -.100 & $(.035)$ & .320 & $(.045)$ & .104 & $(.040)$ \\
\hline Observations & & & & & & & 551 & \\
\hline Spells & & & & & & & & \\
\hline Transitions & & & 548 & & & & 708 & \\
\hline Log likelihood & & & & & & & 495 & \\
\hline Pseudo- $R^{2}$ & & & 209 & & & & 435 & \\
\hline
\end{tabular}

Notes: The data set used is version 2 of the LIAB longitudinal model. The dependent variable of the (stratified) Cox models is a dummy variable taking the value one if the individual changes from an IAB Panel-establishment to employment or non-employment, respectively, and zero otherwise. Standard errors clustered at the individual level are given in parentheses. Only establishments with 5-1,000 employees and spells ending or beginning in 2000-2002 are considered. 
transition behaviour ${ }^{21}$ With respect to the other covariates, all our earlier findings carry over qualitatively.

\section{Conclusions}

In this paper, we have investigated gender differences in transition probabilities into employment and nonemployment using a large German linked employer-employee data set, the LIAB, and methods of competing risks survival analysis. We argued that due to domestic responsibilities women should be less inclined to make job-to-job moves, likely to reflect wage-improving voluntary quits, whereas they should have a higher propensity of leaving their jobs to nonemployment. We fitted conditionally independent competing risk models, where the route-specific instantaneous separation rates to employment and nonemployment are modelled as stratified Cox models. Including a female dummy in the hazard rate models, we corroborated these hypotheses. Insofar, our results confirm existing studies, such as Royalty (1998) and Frederiksen (2008), stressing the offsetting gender effects of job-to-job and job-to-nonemployment transitions.

Furthermore, our analysis makes clear that both individual and workplace characteristics affect workers' transition behaviour. This is in line with Frederiksen's (2008) findings based on very few workplace characteristics. Moreover, the richness of our data set allowed us to apply continuous-time hazard rate modelling for the destinationspecific separation rates and thus accounting for unobserved plant heterogeneity by estimating stratified Cox models. This is of particular importance to account for gender segregation in the labour market likely to be reflected both in observed and unobserved workplace characteristics. We therefore argue that our results, which are nevertheless not contradictory to previous findings, are considerably more reliable. What is more, we also found that several workplace characteristics, such as the establishment's industrial relations regime, its workforce composition, and its technological and profitability status, affect workers' separation probabilities differently by gender and that the coefficients of the catch-all female dummies in both destination-specific hazard rate models lose significance once accounting for these gender differences.

When including the worker's wage as additional regressor, we found that both separations to employment and nonemployment are significantly less wage-elastic for women than for men. This affirms previous studies investigating gender differences in separation rate wage elasticities, such as Barth and Dale-Olsen (2009), Hirsch et al. (2010a), as well as Ransom and Oaxaca (2010). By explicitly accounting for unobserved plant heterogeneity, we even improve on these studies and put their finding on a firmer

$21 \quad$ Again, we have to admit that ideally we would have checked whether gender differences in separation rate elasticities and levels are primarily present for married women with children at home as opposed to childless single women for whom domestic constraints should not play a role. Unfortunately, this is not possible due to the absence of such information in our data. 
footing. In line with less wage-elastic transition behaviour of women, we found that separation rates both to employment and nonemployment are considerably lower for women than for men when controlling for the wage. Given that there exist (unexplained) gender pay gaps in reality, observed patterns of gender differences in transition behaviour seem to reflect wage elasticity effects, wage level effects, and effects stemming from differences in (other) individual and workplace characteristics of men and women.

Yet, there remains one serious caveat. Regrettably, our data set contains no (reliable) information on workers' marital status and number of children. Such information would have allowed us to investigate in more detail whether gender differences in transition behaviour are due to family-related reasons and to which extent family policy instruments may influence women's separation rates. In spite of this limitation, our analysis has shed new light on the relevance of individual and workplace characteristics for workers' transition behaviour. By identifying some gender-specific impacts hitherto neglected we have shown that women indeed move differently (and for different reasons) than men. 


\section{References}

Alda, H., Bender, S., and Gartner, H. (2005), 'The linked employer-employee dataset created from the IAB establishment panel and the process-produced data of the IAB (LIAB),' Schmollers Jahrbuch (Journal of Applied Social Science Studies), 125(2):327-336.

Anderson, P.M. and Meyer, B.D. (1994), 'The extent and consequences of job turnover,' Brookings Papers on Economic Activity. Microeconomics, 1994:177-248.

Bartelheimer, P. and Wieck, M. (2005), 'Arbeitslosigkeit und Unterbeschäftigung,' in Soziologisches Forschungsinstitut, Institut für Arbeitsmarkt- und Berufsforschung, Institut für Sozialwissenschaftliche Forschung, and Internationales Institut für empirische Sozialökonomie (eds.), 'Berichterstattung zur sozioökonomischen Entwicklung in Deutschland - Arbeit und Lebensweisen. Erster Bericht,' pp. 271302, Wiesbaden: VS Verlag für Sozialwissenschaften.

Barth, E. and DAle-Olsen, H. (2009), 'Monopsonistic discrimination, worker turnover, and the gender wage gap,' Labour Economics, 16(5):589-597.

Bender, S., HaAs, A., and Klose, C. (2000), 'The IAB Employment Subsample 197595,' Schmollers Jahrbuch (Journal of Applied Social Science Studies), 120(4):649662.

Blau, F.D. and Kahn, L.M. (1981), 'Race and sex differences in quits by young workers,' Industrial and Labor Relations Review, 34(4):563-577.

Burda, M.C. and Mertens, A. (2001), 'Estimating wage losses of displaced workers in Germany,' Labour Economics, 8(1):15-41.

Cameron, A.C. and Trivedi, P.K. (2005), Microeconometrics: Methods and Applications, Cambridge: Cambridge University Press.

Cox, D.R. (1972), 'Regression models and life-tables,' Journal of the Royal Statistical Society, Series B (Methodological), 34(2):187-220.

(1975), 'Partial likelihood,' Biometrika, 62(2):269-276.

Frederiksen, A. (2008), 'Gender differences in job separation rates and employment stability: New evidence from employer-employee data,' Labour Economics, 15(5):915-937.

Hirsch, B. (2009), 'The gender pay gap under duopsony: Joan Robinson meets Harold Hotelling,' Scottish Journal of Political Economy, 56(5):543-558.

(2010), Monopsonistic Labour Markets and the Gender Pay Gap: Theory and Empirical Evidence, Berlin and Heidelberg: Springer.

Hirsch, B., Schank, T., and Schnabel, C. (2010a), 'Differences in labor supply to monopsonistic firms and the gender pay gap: An empirical analysis using linked employer-employee data from Germany,' Journal of Labor Economics, 28(2):291330. 
- (2010b), 'Works councils and separations: Voice, monopoly, and insurance effects,' Industrial Relations, forthcoming.

Jacobebbinghaus, P. (2008), LIAB-Datenhandbuch Version 3.0, Forschungsdatenzentrum des Instituts für Arbeitsmarkt- und Berufsforschung, Nuremberg, Datenreport Nr. 3/2008.

Jenkins, S.P. (2005), Survival Analysis, unpublished manuscript, Institute for Social \& Economic Research, University of Essex.

Klein, J.P. and Moeschberger, M.L. (2003), Survival Analysis: Techniques for Censored and Truncated Data, New York: Springer, 2nd edn.

KÖLling, A. (2000), 'The IAB-Establishment Panel,' Schmollers Jahrbuch (Journal of Applied Social Science Studies), 120(2):291-300.

Light, A.L. and Ureta, M. (1992), 'Panel estimates of male and female job turnover behavior: Can female nonquitters be identified?' Journal of Labor Economics, 10(2):156-181.

Manning, A. (2003), Monopsony in Motion: Imperfect Competition in Labor Markets, Princeton, NJ: Princeton University Press.

OECD (2010), 'How do industry, firm and worker characteristics shape job and worker flows?' in 'OECD Employment Outlook 2009,' chap. 2, pp. 117-163, Paris: OECD.

Postel-Vinay, F. and Robin, J.M. (2002), 'Equilibrium wage dispersion with worker and employer heterogeneity,' Econometrica, 70(6):2295-2350.

Ransom, M.R. and OAXACA, R.L. (2010), 'New market power models and sex differences in pay,' Journal of Labor Economics, 28(2):267-290.

Ridder, G. and TunAli, İ. (1999), 'Stratified partial likelihood estimation,' Journal of Econometrics, 92(2):193-232.

Robinson, J.V. (1933), The Economics of Imperfect Competition, London: Macmillan.

Royalty, A.B. (1998), 'Job-to-job and job-to-nonemployment turnover by gender and education level,' Journal of Labor Economics, 16(2):392-443.

Therneau, T.M. and Grambsch, P.M. (2000), Modeling Survival Data: Extending the Cox Model, New York: Springer.

VAN DEN BerG, G.J. and RIDDER, G. (1998), 'An empirical equilibrium search model of the labor market,' Econometrica, 66(5):1183-1221.

Viscusi, W.K. (1980), 'Sex differences in worker quitting,' Review of Economics and Statistics, 62(3):388-398. 
Table A.1: Descriptive statistics of the employment spells (sample averages)

\begin{tabular}{|c|c|c|c|}
\hline & All & Women & Men \\
\hline Female (dummy) & .268 & 1.000 & .000 \\
\hline Log daily gross wage & 4.518 & 4.372 & 4.572 \\
\hline $\begin{array}{l}\text { Spell with a censored wage observation in any } \\
\text { of the years 2000-2002 (dummy) }\end{array}$ & .131 & .050 & .161 \\
\hline Non-German (dummy) & .082 & .074 & .085 \\
\hline Tenure (number of years) & 8.964 & 8.797 & 9.025 \\
\hline Age under 21 years (dummy) & .007 & .011 & .006 \\
\hline Age $21-25$ years (dummy) & .063 & .090 & .053 \\
\hline Age $26-30$ years (dummy) & .127 & .150 & .118 \\
\hline Age $31-35$ years (dummy) & .183 & .169 & .189 \\
\hline Age $36-40$ years (dummy) & .190 & .161 & .201 \\
\hline Age $41-45$ years (dummy) & .165 & .154 & .169 \\
\hline Age $46-50$ years (dummy) & .145 & .150 & .143 \\
\hline Age $51-55$ years (dummy) & .105 & .101 & .107 \\
\hline Age $56-58$ years (dummy) & .015 & .014 & .016 \\
\hline No apprenticeship, no Abitur (dummy) & .176 & .192 & .170 \\
\hline Apprenticeship, no Abitur (dummy) & .656 & .641 & .662 \\
\hline No apprenticeship, with Abitur (dummy) & .010 & .014 & .009 \\
\hline Apprenticeship and Abitur (dummy) & .049 & .072 & .041 \\
\hline Technical college degree (dummy) & .049 & .030 & .055 \\
\hline University degree (dummy) & .060 & .052 & .063 \\
\hline Basic manual occupation (dummy) & .239 & .153 & .271 \\
\hline Qualified manual occupation (dummy) & .165 & .042 & .210 \\
\hline Engineers and technicians (dummy) & .112 & .044 & .137 \\
\hline Basic service occupation (dummy) & .092 & .052 & .106 \\
\hline Qualified service occupation (dummy) & .018 & .046 & .008 \\
\hline Semi-professional (dummy) & .055 & .132 & .027 \\
\hline Professional (dummy) & .021 & .024 & .020 \\
\hline Basic business occupation (dummy) & .053 & .108 & .033 \\
\hline Qualified business occupation (dummy) & .219 & .383 & .159 \\
\hline Manager (dummy) & .026 & .017 & .029 \\
\hline Works council (dummy) & .855 & .857 & .854 \\
\hline Coll. agreement at sect. level (dummy) & .741 & .728 & .746 \\
\hline Coll. agreement at firm level (dummy) & .108 & .105 & .109 \\
\hline Proportion of female workers & .347 & .522 & .284 \\
\hline Proportion of qualified workers & .705 & .712 & .703 \\
\hline Proportion of fixed-term workers & .063 & .069 & .061 \\
\hline Bad economic performance (dummy) & .221 & .191 & .232 \\
\hline New production technology (dummy) & .734 & .738 & .732 \\
\hline Establishment size & 379.018 & 386.500 & 376.279 \\
\hline Regional unemployment rate (lagged, \%) & 9.195 & 9.334 & 9.144 \\
\hline Year 2000 (dummy) & .351 & .348 & .352 \\
\hline Year 2001 (dummy) & .325 & .322 & .327 \\
\hline Year 2002 (dummy) & .324 & .330 & .322 \\
\hline Spells & 216,032 & 57,898 & 158,134 \\
\hline Separations to employment & 38,608 & 9,309 & 29,299 \\
\hline Separations to non-employment & 23,501 & 7,121 & 16,380 \\
\hline
\end{tabular}

Note: The data set used is version 2 of the LIAB longitudinal model. Only establishments with 5-1,000 employees and spells beginning or ending in 2000-2002 are considered. 


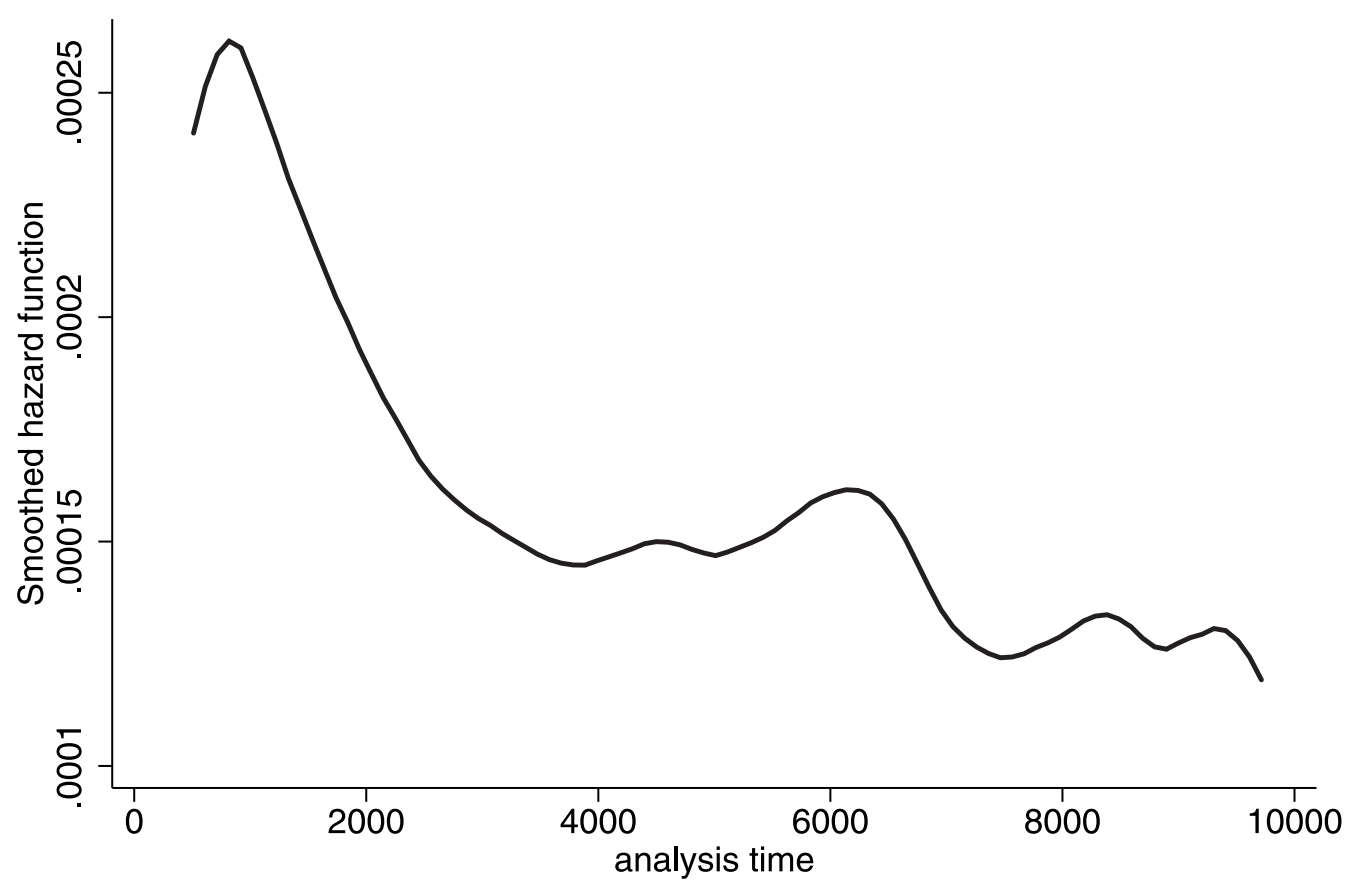

Figure A.1: Smoothed Nelson-Aalen baseline hazard after Cox regression of the workers' instantaneous separation rate to employment

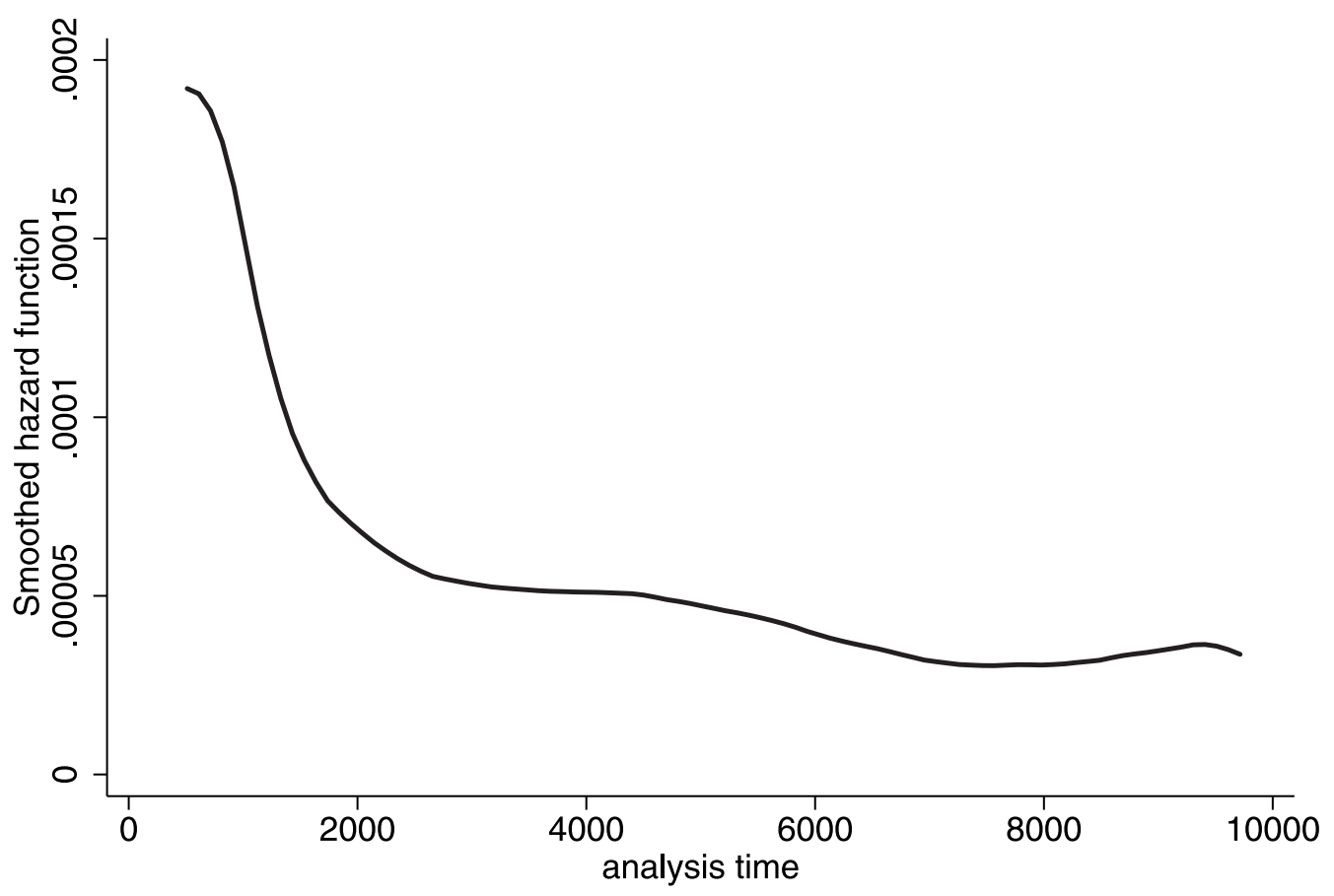

Figure A.2: Smoothed Nelson-Aalen baseline hazard after Cox regression of the workers' instantaneous separation rate to nonemployment 